\title{
INVESTIGATION INFLUENCE OF STORE TYPE ON EMOTIONAL STATE OF CONSUMER IN THE URBAN PURCHASE
}

\author{
Andrii HALKIN*, Kseniia BLIUMSKA-DANKO**, Olena SMIHUNOVA***, \\ Elena DUDNYK $* * * *$, Iryna BALANDINA***** \\ *O. M. Beketov National University of Urban Economy, Kharkiv, UKRAINE \\ e-mail: galkin.tsl@gmail.com \\ **Sumy National Agrarian University, Sumy, UKRAINE \\ e-mail: kseniiabliumska@gmail.com \\ ***Kharkiv National Technical University of Agriculture named after Petr Vasilenko, Kharkiv, UKRAINE \\ e-mail: elenasmigunova@gmail.com \\ ****Kharkiv National Technical University of Agriculture named after Petr Vasilenko, Kharkiv, UKRAINE \\ e-mail: elenadudnyk88@gmail.com \\ *****O. M. Beketov National University of Urban Economy, Kharkiv, UKRAINE \\ e-mail: irinabalandina2511@gmail.com
}

\begin{abstract}
The shopping service of the store plays an important role in shaping the opinions of customers in a store. Endless progress has been made on quality management of consumer services confirmed through numerous methods and standards that are based on consumers. A typical consumer receives a large amount of information in the shopping process. In the process of perception of this information, consumer must not only find necessary data, but also process, analyze, and evaluate this date, and weigh the pros and cons, relate it to his own needs, and at the end, make a decision: to buy or not to buy a certain product. All these reflect on consumer's fatigue, stress, and other negative fallings obtained during any shopping. In this case, the buyer can make the wrong choice and the quality of his decisions would deteriorate. Therefore, investigation influence of store type on the emotional state of consumers in the urban purchase provides significant reserve for marketing development in this sphere. Research provides explanation of emotional fatigue on the type of stores. The regression models describing the shift in emotional state of the buyer in purchase process of different type of shops were obtained. Research was conducted in the residential area of Kharkiv, Ukraine. The presented model shows the average value of the indicator of the emotional system of buyers after shopping, which can be used to determine the likelihood of shopping on the basis of emotional fatigue.
\end{abstract}

Keywords: customer, emotion, state, purchase, GSR.

JEL: M31, M39, C93, D19, L69.

\section{1}

\section{Introduction}

From the point of view of the retailer, the objective of marketing and advertising influence in retail is not the specific goods on the shelves, but the complex service that the store provides. Usually, it is standardized, therefore, no matter how much they talk about "high quality of service", "wide assortment" and "low prices", in the conditions of high competition between retailers, sooner or later, the emotional impact on the buyer comes first - it is called the atmosphere of the store (Crosby, Evans and Cowles, 1990). The atmosphere of the store is a combination of factors and conditions created in a trading enterprise and designed to evoke in visitors a certain emotional state that can affect their buying behavior (Ghobadian, Speller and Jones, 1994). The main task of forming the atmosphere of the store is to meet the goals of merchandising and help to increase sales. That is, the atmosphere of the store should be shaped in such a way that visitors concentrate their attention in the right direction, and the likelihood of making purchases of those goods that without such interference cannot attract attention and interest potential buyers is sufficient so that they buy them. 
In a situation where several trading enterprises sell the same goods at similar prices, the success of the retailer often depends on the atmosphere of the store and the chosen way of shopping service (TS). Therefore, stores should monitor not only the level of prices, but also the image, in order to most closely match the needs of their customers.

\section{The concept and main factors of the formation of the atmosphere of the store}

\subsection{Assessing the level of shopping service}

In the conditions of market relations that have developed in the world in recent years, the process of trade customer service becomes the most important object of control and economic research at retail enterprises. The quality of trade services directly affects the image of the trade organization and is its important resource of competition. One of the main indicators characterizing the process of customer service is the level of quality of trade services. This indicator is multifaceted, including a number of separate indicators, such as customer service culture, the speed of shopping service, the stability of the product range, the range of services provided to customers and much more. In fact, the level of quality of trade services is an indicator of the quality of functioning of the service system in a retail trade enterprise.

The scientific literature presents various approaches to the study of the quality of services, most of which are theoretical, which makes it difficult to apply them in practice. One of the first fundamentally studied key parameters of stores was the quality of service and convenience of shopping (Jun, Yang and Kim, 2004). However, the results of these studies were quite obvious - the high quality of service has a positive effect on the decision to purchase. A new reading of this question was received only in the works of recent years (Etzion and Pang, 2014), in which the influence of service components on the level of profitability of online stores has been proved. Moreover, the perception of the service level is considered not only in isolation from the external environment, but also in comparison with the proposals of competitors.
Most often, the subject of the study, directly or indirectly, are factors affecting the behavior of customers. Purchasing behavior, as follows from the wellknown "S-O-R" model (Woodworth and Schlosberg, 1954) and its modifications "S-H-O-H-R" (Piaget, 2017) and (Feuerstein, Klein, and Tannenbaum, 1991), are influenced by incentives aimed at buyers by sellers, including in the places of sale of goods. Such factors cause a positive or negative impact on the purchase of goods (Cummings and Venkatesan, 1976; Dennis, et al., 2010).

The authors systematized the corresponding reactions in the PAD model (pleasure-displeasure; arousal-no arousal; dominance-submissiveness), which demonstrates the three-dimensional emotional perception of the atmosphere of the place of sale: pleasure-displeasure; excitement-non-excitation; domination-submissiveness (Chang, Eckman and Yan, 2011; Krey, Espinosa and Cao, 2017).

The importance of factors shaping the favorable atmosphere of the place of sale, such as lighting, location of goods, sounds, color, air temperature, and others to stimulate perceptual and emotional types of consumer response is regarded in the work (Kotler, 1973). In the subsequent period, a large number of researchers began to study the effect of these factors on consumer behavior (Bhatt, 2017). It is advisable for the purposes of this work to systematize the available data on this topic into two main parts.

One part of the research on this topic considers the atmosphere of a place of sale as a holistic concept, focusing on the integral effect of its various elements in relation to the impact on consumer behavior (McGoldrick and Pieros, 1998; Dennis, et al., 2010). The other part, on the contrary, contains studies that focus on individual elements of the atmosphere of the place of sale of a physical nature, such as color (Bellizzi and Hite, 1992; Babin, Hardesty and Suter, 2003), lighting (Areni and Kim, 1993), aroma (Morrison, et al., 2011) and background music (Jain and Bagdare, 2011).

In general, the factors of a physical nature are well studied by specialists in the field of marketing communications and are used in the practice of retail. Exterior atmospherics from landscaping the external 
part and store's window displays is regarded in the work (Mower, Kim and Childs, 2012).

In addition to the factors of physical nature in the atmosphere of a place of sale, factors of a social nature also take part, including diverse relationships between individual buyers, both among themselves and with the personnel of the place of sale, as well as with other participants of the distribution, for example, with reference groups influencing consumer behavior (as mentioned earlier) (Puccinelli, et al., 2009). Important factors of a social nature that influence the behavior of customers are culture, social class, reference groups, lifestyle, and so on.

Cultural factors in the social environment of places of sale can determine the lifestyle learned by customers, helping them to perceive and evaluate the surrounding trading atmosphere, communicate both among themselves and with the personnel of the place of sale (Kumar, Garg and Rahman, 2010). They determine and significantly affect consumer behavior, as they define the limits of so-called "acceptable" behavior.

People's values, attitudes, and beliefs influence the perception of a place of sale both as a whole and in its individual elements, which predetermines consumer behavior both inside the place of sale (the situation of choice and making a purchase decision) and outside it (the situation of consumption of the purchased goods) (Lovelock and Patterson, 2015). There are relatively permanent models of consumer behavior within a single social class: consumer habits, choice of sources of information, and so on (Levy, Weitz and Grewal, 2012).

Formal reference groups (e.g., the family) pay increased attention to teaching their members the necessary consumer patterns, while the informal ones are characterized by less clear patterns of consumer behavior, especially with regard to financing purchases, choosing sources of information, ways to meet needs (Kotler and Armstrong, 2010). However, despite the differences, reference groups, as a self-governing social unit, are characterized by approximately the same algorithm of impact on the buyer (Blackwell, Miniard and Engel, 2006).

The same person can be a member of several reference groups and because of this, consumers often unconsciously transfer respect to their idols - the leaders of reference groups to those trademarks that these idols use in their life style (De Mooij and Hofstede, 2011). Despite the numerous availability of publications and research in this field, consumer behavior in the retailers has not been fully considered. There are practically no studies of the influence of the atmosphere in the various types of stores on the consumer in a real environment using medical devices. However, until now, the reliable methods of forming a mental environment and operational methods for monitoring and managing the psychology of visitors of the trading floor have not been found yet.

\subsection{Neuromarketing concept for assessing consumer}

In the last 20 years, factors associated with the senses and their influences on consumer behavior have gained special interest. Such sensory marketing was allocated to a separate category - neuromarketing. Neuromarketing concept engages the use of technologies to investigate and learn how consumers respond and feel when presented with products and/or related stimuli (Plassmann, et al., 2007), especially consumer's brain (Agarwal and Dutta, 2015; Glanert, 2012).

Human body also has an impact on consumer's activities. In addition to brain methods, it allows to measure fatigue state, emotional reaction of body, functional state of organism (Afanasieva and Galkin, 2018; Baevsky, 1984) using pulse rate, galvanic skin respond, EEG oculography, and so on. So, we put this principle as a basis for conducting researches and use medical equipment (galvanic skin respond and heart rate analysis) for measuring the buyer. Unlike other methods of assessing of the functional state of the body, GSR determines the body's reaction to stimuli in real time and allows to measure the time of the reaction and its force in response to a particular stimulus (Lykken and Venables, 1971; Boucsein, 2012).

Another advantage of the GSR usage (as compared with EEG, for example) is its invisibility during the experiment. GSR was used for the measurement of emotion in other scientific fields also (Jerritta, 
et al., 2011; Kim, et al., 2011); therefore, it can be used in the analysis of customers too. Cardio rhythms variability analysis during the assessment of the stress level had a wide use (Chebykin, Bedny and Karwowski, 2008).

The behavior of the buyer is a complex human reaction that results in the making of the purchase or refusing it (Bakker, Pechenizkiy and Sidorova, 2011). The reasons of failure of the set goals of purchases can be the following: insufficient range, service, prices, and other more subjective factors, which depend on the person, such as fatigue. Buyer's fatigue is not a new notion in consumer behavioral theory.

The external signs of fatigue include: increased sweating, breathing rhythm disturbances, and poor coordination of movements. The internal features include: the emergence of pain in muscles and dizziness (Baevsky, 1984; Charlton, 2002; Rigas, et al., 2008). Consumer behavior studies attempt to understand the decision-making processes of buyers and how emotions can affect them. They also try to assess the influences on the consumer from different groups such as family, friends, sports, reference groups, and society in general (Andreassi, 2007; Minton and Khale, 2014). There are three types of fatigue (Frenkel, 1966): physical, mental, and emotional. They often occur simultaneously.

Physical stress of the buyer on the basis of continuous improvement of technical and technological means of shopping centers (cars and shopping carts, escalators, automatic doors, delivery services, Internet shopping) is constantly declining. Yet reserves of the reducing fatigue by creating comforts and ease of committing purchases are still great. Buyer is faster physically tired after long travel to the shopping center and long waiting time before the cashier. Irrational layout of exhibition stands complicates the choice of the right product (Adolphs, 2002).

According to marketers and psychologists (Grewal, Levy and Kumar, 2009), mental fatigue occurs faster while long visits to the big shopping halls with a huge variety of goods and choice. After the analysis and comparison of different brands, buyer makes a choice, which is always a compromise.
Almost every big purchase causes an internal conflict - a feeling of dissatisfaction, which is caused by doubts about the correctness of the choice made. During this period, the buyer is satisfied with the benefits of the purchased goods. He realizes that he avoided the shortcomings that exist in other brands, but also understands that he missed their benefits. So after every purchase, consumer feels an internal conflict - at least in a minimal degree. Big amount of purchases leads to the acceleration of the process of mental fatigue.

Emotional fatigue is caused by negative feelings in the shopping process (Chebat, Dube and Marquis, 1997). If a product does not meet the expectations, the buyer is not satisfied, if the product meets the expectations - the buyer is satisfied and if the product exceeds expectations, the buyer is also satisfied. The greater is the difference between expectations and actual results, the greater is consumer's frustration (Marsha, 1997). Prolonged emotional stress causes tension, stress, or nervous breakdown.

Previous studies in this area found that a certain voltage level is necessary to maintain the normal life in average state both in terms of relative calm and in the usual activities (Halkin, 2018). However, overstrain of regulation system can lead to the disruption of adaptation and inadequate change in the functioning of the major body systems with the emergence of pathological syndromes and diseases (Baevsky, et al., 2001).

Subjectively, fatigue can be felt as tiredness (Ambler, et al., 2004). Fatigue manifests itself in a temporary decrease of efficiency. Fatigue can be measured only by the amount of the performed work, the purchase quantity or the amount of the check. Many factors influence buyer in the process of shopping (socio-cultural, personal, psychological factors, situational influence, marketing influence), each of which may have a decisive influence on the magnitude and timing of fatigue (Kotler and Kelle, 2012) and as a result, the buyer will make a purchase or not.

Considering review, there are very few studies of human behavior conducted in real environment. There has not been much use of medical equipment for measuring emotional fatigue, and none for evalu- 
ating the effect of the type of store for purchase on emotional fatigue via medical equipment. This indicates the science gap in modern marketing analysis for understanding the behavior of consumers in various types of stores.

As a result, marketing technologies for the work with consumers remain understudied and poorly used resources, which does not effectively implement the actual and very significant (in terms of economic results) marketing principle of customer focus. The key problem in this case remains the lack of theoretical models and practical mechanisms for the formation and effective use of neuromarketing technologies in assessing the quality of retail service.

The author sees the solution of the problem in the need to develop a methodological approach based on the interconnection of classical marketing technologies and neuromarketing methods, and on this basis, build conditions for creating a comprehensive assessment of retailers' service, taking into account the maximum number of factors and incentives in it.

Therefore, the specific objectives of this paper are:

1) to established a method for assessing the shift of level of emotional elastic reaction of buyer between the elements of purchase process and on time;

2) to conduct experiments on different consumers who visit different stores and evaluate their emotional state on different types of stores;

3) to process the obtained data on different types of stores.

\section{Tasks, design, and procedure}

\subsection{Method statement}

Measuring the degree of emotional stress is determined by the magnitude of indicators that objectively record physiological changes (amplitude and duration of skin-galvanic reactions). To assess the shift of the level of buyer emotional reaction $\left(\Delta \mathrm{E}_{\mathrm{i}}\right)$, dependence was used (Halkin, 2018). Resulting deviation from back-to-back elements of purchase process shows emotional fatigue on it:

$$
\Delta \mathrm{E}_{\mathrm{i}}^{\mathrm{GSR}}=\frac{\left(\mathrm{GSR}_{\mathrm{i}-1}-\mathrm{GSR}_{\mathrm{i}}\right)}{\mathrm{GSR}_{\mathrm{i}}} \cdot 100 \%,
$$

where:

$\mathrm{GSR}_{\mathrm{i}-1}$ - microsiemens value at previous element of purchase process, $\mathrm{mSm}$,

GSR $_{i}$ - microsiemens value at the current element of purchase process, $\mathrm{mSm}$.

A trip to the store causes various losses, including emotional ones. This is especially true for daily purchases, which are repeated systematic and do not bring positive emotions, because people have to make them. The shift of the level of p-buyer emotional reaction when visiting a $j$-th store can be subdivided into the elements of the purchasing process that affects the buyer's emotional state:

$$
\Delta \mathrm{E}_{\mathrm{pj}}^{\mathrm{GSR}}=\sum_{\mathrm{i}=1}^{\mathrm{N}} \Delta \mathrm{E}_{\mathrm{i}}^{\mathrm{GSR}}=\Delta \mathrm{E}_{\mathrm{road}}^{\mathrm{GSR}}+\Delta \mathrm{E}_{\mathrm{TS}}^{\mathrm{GSR}}+\Delta \mathrm{E}_{\text {other }}^{\mathrm{GSR}}
$$

where:

$\Delta \mathrm{E}_{\mathrm{pj}}^{\mathrm{GSR}}$ - the shift of level of $\mathrm{p}$-buyer emotional reaction when visiting a $\mathrm{j}$-th store,

$\Delta \mathrm{E}_{\mathrm{R}}^{\mathrm{GSR}}$ - the shift of level of $\mathrm{p}$-buyer emotional reaction on the way to the $\mathrm{j}$-th store,

$\Delta \mathrm{E}_{\mathrm{TS}}^{\mathrm{GSR}}$ - the shift of level of p-buyer emotional reaction at trade servicing in the $\mathrm{j}$-th store,

$\Delta \mathrm{E}_{\mathrm{other}}^{\mathrm{GSR}}$ - the shift of level of p-buyer emotional reaction at other elements of the purchasing process in the $\mathrm{j}$-th store.

Another important issue is the relationship between the shifts in emotional fatigue of buyers at different stages of the purchase process. Not only being in the store causes emotions in the shopping process, and as it was said earlier in our studies, the road also affects the emotional state of the buyer (Halkin, 2016). And the question that remains unsolved is: "What tires the buyer more: the road or the purchases themselves?". In some cases, buyers choose the nearest store for purchases, but with higher prices there. In other cases, buyers agree to go or to drive further in order to obtain a wider range of products, high service, lower price, and so on.

The reaction of buyers in both cases should be different $\left(\mathrm{H}_{1}\right)$, but when considering in the system, one and the same buyer can get tired the same way in both variants, when returning home. Thus, it can be argued that there is a certain point of equilibrium 
between emotional fatigues when being inside a store and on the way to it, which can be determined as the shift of the level of emotional elastic reaction of the buyer's factor between the elements of the purchase process:

$$
\mathrm{E}_{\mathrm{TS} / \mathrm{R}}^{\mathrm{GSR}}=\frac{\Delta \mathrm{E}_{\mathrm{pji}}^{\mathrm{GSR}}}{\Delta \mathrm{E}_{\mathrm{pji}-1}^{\mathrm{GSR}}}=\frac{\Delta \mathrm{E}_{\mathrm{TS}}^{\mathrm{GSR}}}{\Delta \mathrm{E}_{\mathrm{R}}^{\mathrm{GSR}}},
$$

where:

$\Delta E_{p j}^{G S R}$ - the shift of level of emotional reaction $p$ buyer while visiting j store.

Therefore, there can be 3 options for this factor:

- if the shift of the level of emotional elastic reaction of buyer factor is $1\left(\mathrm{E}_{\mathrm{TS} / \mathrm{R}}^{\mathrm{GSR}}=1\right)$, then the reaction to road and trade is equal,

- if the shift of the level of emotional elastic reaction of buyer factor is less than $1\left(\mathrm{E}_{\mathrm{TS} / \mathrm{R}}^{\mathrm{GSR}}<1\right)$, then the growth changes of shift of the level of the buyer emotional reaction of the buyer will be more at the store than on the road to it,

- if the shift of the level of emotional elastic reaction of buyer factor is more than $1\left(\mathrm{E}_{\mathrm{TS} / \mathrm{R}}^{\mathrm{GSR}}>1\right)$, then the growth changes of shift of the level of the buyer emotional reaction of the buyer will be more on the road than at the store.

Emotional elasticity is a category that characterizes the shift in the emotional reaction of a buyer, depending on the execution time of the elements of the purchases process, that is, the reaction of buyers at the time change $\left(\mathrm{H}_{2}\right)$. The factor of shift of level of emotional elastic reaction of buyer's factor on time can be found as:

$$
\mathrm{E}_{\Delta \mathrm{E} / \mathrm{T}}^{\mathrm{GSR}}=\frac{\Delta \mathrm{E}_{\mathrm{pji}}^{\mathrm{GSR}}}{\Delta \mathrm{T}_{\mathrm{pji}}}=\left\{\begin{array}{l}
\frac{\Delta \mathrm{E}_{\mathrm{TS}}^{\mathrm{GSR}}}{\mathrm{T}_{\mathrm{TS}}} ; \text { for tradeserviceelement } \\
\frac{\Delta \mathrm{E}_{\mathrm{R}}^{\mathrm{GSR}}}{\mathrm{T}_{\mathrm{R}}} ; \text { for road tost oreelement }
\end{array}\right.
$$

where:

$T_{T S}, T_{R}$ - time of continuation of the element's purchase process, min.
If the reaction increases with time $\left(\mathrm{E}_{\mathrm{TS} / \mathrm{R}}^{\mathrm{GSR}}=1\right)$, this leads to an increase in the emotional fatigue of the buyer; if the reaction does not change, then the state of the buyer remains unchanged $\left(\mathrm{E}_{\mathrm{TS} / \mathrm{R}}^{\mathrm{GSR}}<1\right)$, in this case, incentives do not affect the consumer at all or their effect is moderate, which does not lead to significant changes in the emotional state; if the reaction decreases $\left(\mathrm{E}_{\mathrm{TS} / \mathrm{R}}^{\mathrm{GSR}}>1\right)$ then either the buyer is emotionally tired and tries to recover by ignoring the incentives (thinks about something of his own), or an emotional reset takes place. Also, such indicators are characteristic for the pre-sleeping state of the operator.

\subsection{Experiment}

The participants were asked to go to the store, and purchase products from the consumer basket (Lissovolik, 2003) consisting of overall 43 products. There were no limitations (budget, time, etc.) for those purchases. All the participants had been in all the stores previously; the stores are not new for them and they know the goods' locations. One of the residents of Kharkiv was selected for the research (Fig. 1). All the shops were within walking distance (Table 1).

Consumers aged between 25-35 years were examined and the research was conducted in the evening time period from 6:00 pm to 8:00 pm. Overall, 86 experiments on 12 peoples and 10 different stores was carried out. GSR sensor was attached on the left hand on the index and ring fingers (Galkin, et al., 2018).

The video recording was started together with the start of the sensors. We used Kotler's scheme of the consumer's decision-making process on buying a product (Kotler and Keller, 2012). Proceeding from it, "the road to the store" and "shopping service" was considered. 


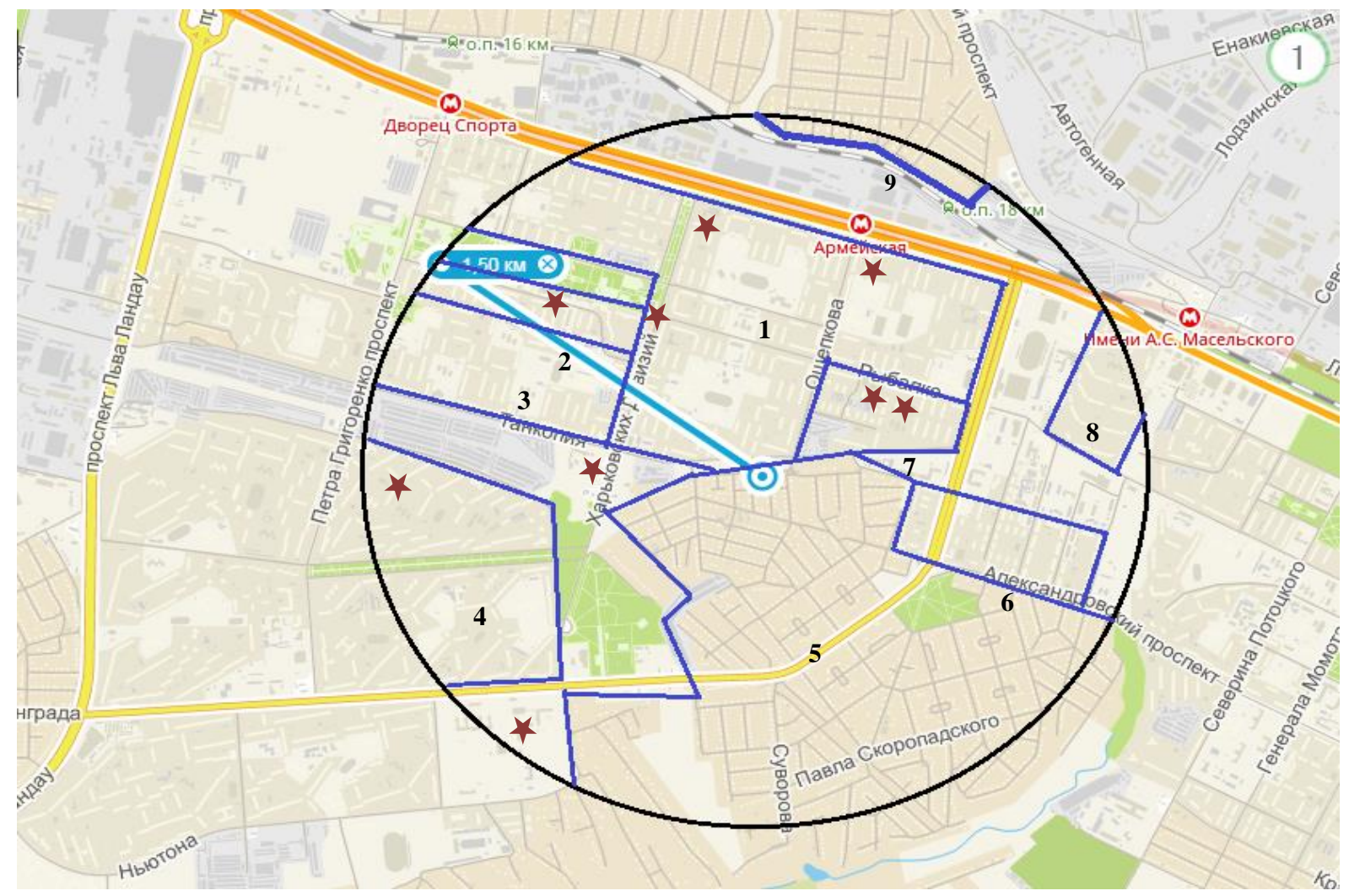

Figure 1. Research residential area

* - stores; 1 - area with 5 floors building; 2 - area with 16 floors building; 3 - area with 5 floors building; 4 - area with multi-story building (5-16 floors); 5 - area with 1 floor building; 6 - area with multi-story buildings (2-5 floors); 7 - area with multi-story buildings (2-5 floors); 8 - area with multi-story building (9-16 floors); 9 - area with 1 floor building (Source: Authors' own research)

Table 1. Information on stores in Research area (Source: Authors' own research)

\begin{tabular}{|c|c|c|c|c|c|}
\hline Store & $\begin{array}{c}\text { Name } \\
\text { of the store }\end{array}$ & $\begin{array}{c}\text { Type } \\
\text { of store }\end{array}$ & $\begin{array}{c}\text { Size of the } \\
\text { store, } \mathrm{M}^{2}\end{array}$ & $\begin{array}{c}\text { Level } \\
\text { of prices }\end{array}$ & $\begin{array}{c}\text { Quality } \\
\text { of service }\end{array}$ \\
\hline A & Silpo & Supermarket & 700 & Average & Average \\
\hline B & No name & Market place (Bazar) & 1408 & Low & Low \\
\hline C & Digma & Supermarket & 550 & Average & High \\
\hline D & ATB & Discounter supermarket & 500 & Lowest & Lower than average \\
\hline E & Digma & Supermarket & 550 & Average & High \\
\hline F & ATB & Discounter supermarket & 400 & Lowest & Lower than average \\
\hline G & ATB & Discounter supermarket & 470 & Lowest & Lower than average \\
\hline H & Chudo & Supermarket & 700 & Average & Average \\
\hline I & ATB & Discounter supermarket & 575 & Lowest & Lower than average \\
\hline K & Grocer & Counter store & 120 & High & Low \\
\hline
\end{tabular}




\section{The results}

\subsection{Assessing the impact of time on the shift of level of buyer emotional reaction at elements of purchase process}

The range of variation of the research data is given in Table 2 and in Fig. 2.

Table 2. Data variation range (Source: Authors' own research)

\begin{tabular}{|c|c|c|c|c|c|}
\hline Parameters & Model 1 & Parameters & Model 1 & Parameters & Model 1 \\
\hline $\begin{array}{c}\text { Measurement bounda- } \\
\text { ries - Total purchase } \\
\text { time Max/min time, } \mathrm{h}\end{array}$ & $0.15 / 2.38$ & $\begin{array}{c}\text { Measurement bounda- } \\
\text { ries - Max/Min emo- } \\
\text { tional shift in GSR }\end{array}$ & $71 / 9$ & $\begin{array}{c}\text { Measurement boundaries - } \\
\text { Max/min time movement } \\
\text { to store, min }\end{array}$ & $46 / 2$ \\
\hline Average time, h & 1.27 & $\begin{array}{c}\text { Average value of } \\
\text { GSR }\end{array}$ & 49.27 & Average time, min & 19.9 \\
\hline $\begin{array}{c}\text { Number of samples in } \\
\text { model, units }\end{array}$ & 86 & $\begin{array}{c}\text { Number of people in } \\
\text { experiments, people }\end{array}$ & 12 & $\begin{array}{c}\text { Mode of samples by one } \\
\text { operator, units }\end{array}$ & 8 \\
\hline Variance of Time & 107.8 & Variance of GSR & 208.4 & Correlation coefficient & 0.61 \\
\hline Student's t-test Actual & 32.02 & $\begin{array}{c}\text { Student's t-test Calcu- } \\
\text { lated }\end{array}$ & 1.97 & Average approximation \\
error
\end{tabular}

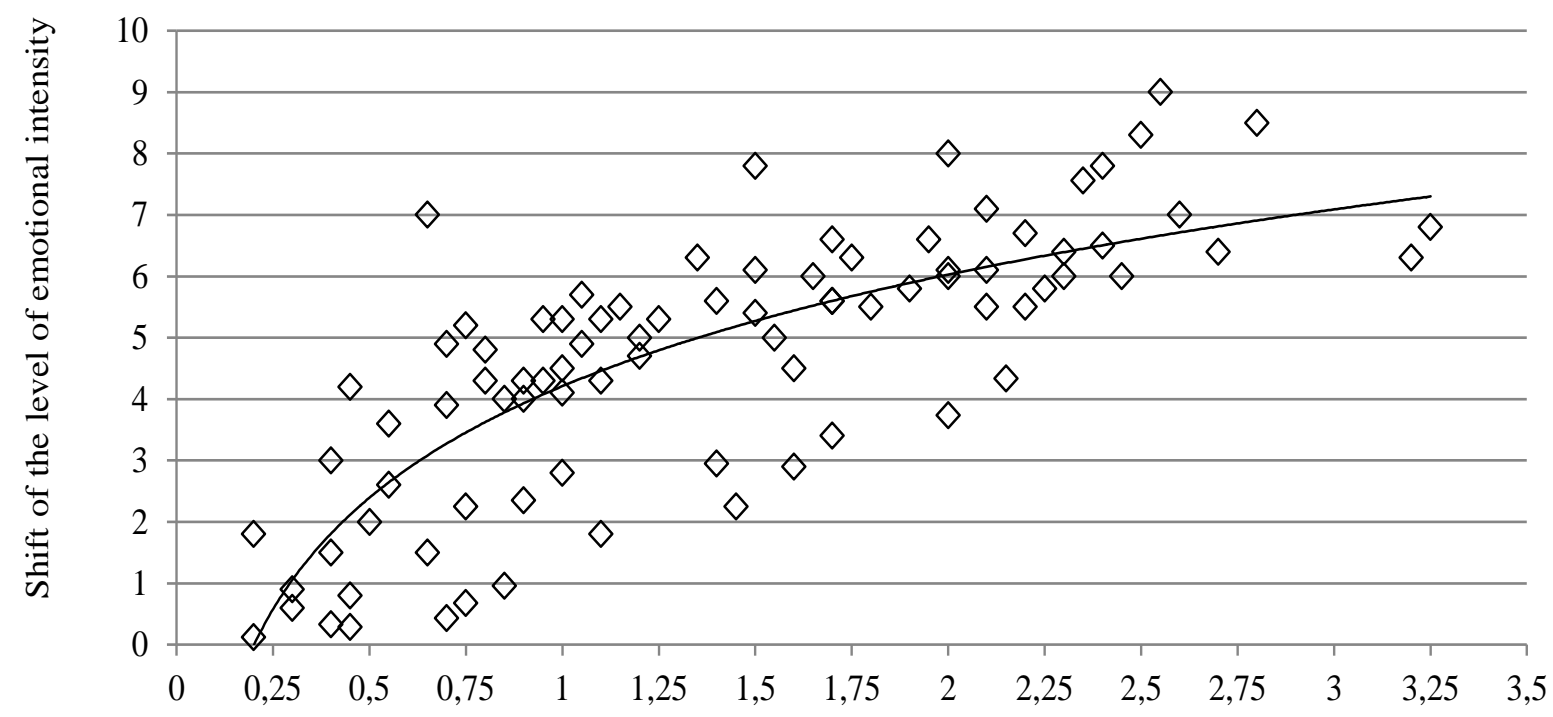

Figure 2. The shift of level of buyer emotional reaction on time to store movement

(Source: Authors' own research)

The results show that the bigger the distance and the time of movement to the store, the bigger will be the shift of level of the buyer emotional reaction (Fig. 2). This indicates the fatigue of the buyer with long trips to distant stores. According to the obtained data, the shift of level of buyer emotional reaction on road to store would be described by the log model:

$$
\mathrm{E}_{\mathrm{R}}^{\mathrm{GSR}}=1,6576^{*} \ln \left(\mathrm{T}_{\text {road }}\right)
$$

The regression coefficients were calculated using the least-squares method. The results of the calculations are given in Tables 2. After the development of the regression model of the shift of level of buyer's emotional reaction on the road to store, its statistical evaluation was conducted. The coefficient of multiple correlation of the model was 0.61 and the average approximation error was $14.3 \%$. The obtained results allows to using the model in practice while 
assessing the level of emotional reaction of consumers on road to store.

The shift of level of p-buyer emotional reaction at the store was assessment (Fig. 3a). The processing of the data did not provide the admissibility of re- sults. Therefore, the data was divided into groups according to the type of store (Fig. 3b). The obtained data was processed and regression models were constructed for each type of store (Table 3).

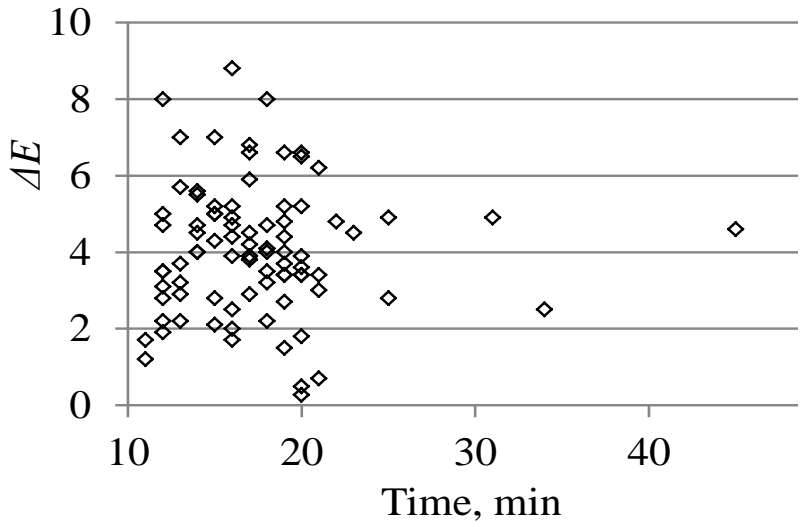

3a) Not divided into group

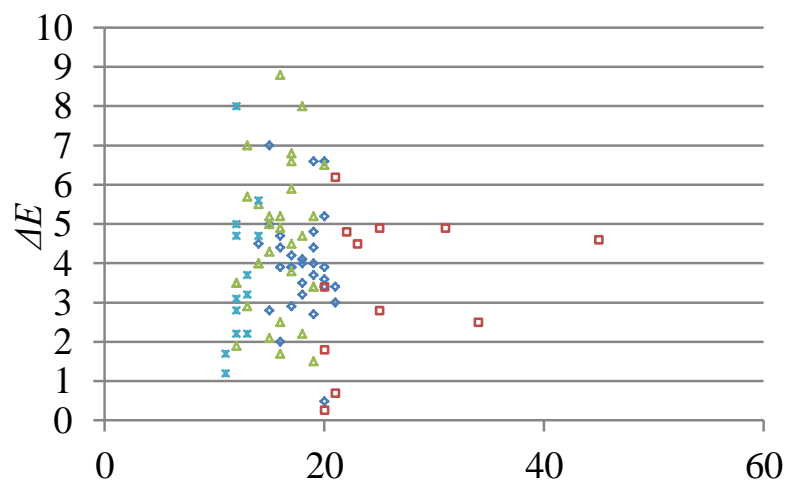

Time, $\min$

$\Delta-$ Discounter supermarket $\quad$ - Counter shops

3b) Stores group by type

Figure 3. Distribution of GSR data on time of shopping service (inside the shop)

(Source: Authors' own research)

Table 3. Characteristics of the models and obtained data

(Source: Authors' own research)

\begin{tabular}{|c|c|c|c|c|}
\hline Parameters & $\operatorname{Model} 2\left(\mathrm{E}_{\mathrm{TS} 1}^{\mathrm{GSR}}\right)$ & Model $3\left(\mathrm{E}_{\mathrm{TS} 2}^{\mathrm{GSR}}\right)$ & Model $4\left(\mathrm{E}_{\mathrm{TS} 3}^{\mathrm{GSR}}\right)$ & Model $5\left(\mathrm{E}_{\mathrm{TS} 4}^{\mathrm{GSR}}\right)$ \\
\hline Type of the shop & $\begin{array}{l}\text { Discount } \\
\text { supermarket }\end{array}$ & $\begin{array}{l}\text { Counter } \\
\text { store }\end{array}$ & Supermarket & $\begin{array}{c}\text { Market } \\
\text { place (Bazar) }\end{array}$ \\
\hline Name of the shop & ATB & Grocery & $\begin{array}{l}\text { Silpo, Digma, } \\
\text { Chudo }\end{array}$ & No name \\
\hline $\begin{array}{l}\text { Number of samples in the } \\
\text { model }\end{array}$ & 31 & 13 & 30 & 12 \\
\hline $\begin{array}{l}\text { Number of people in the ex- } \\
\text { periment }\end{array}$ & 10 & 7 & 10 & 6 \\
\hline $\begin{array}{l}\text { Measurement boundaries - } \\
\text { Max/Min of time in store, min }\end{array}$ & $20 / 12$ & $14 / 11$ & $21 / 14$ & $45 / 19$ \\
\hline Average value, min & 15.87 & 12.4 & 18 & 34.9 \\
\hline $\begin{array}{l}\text { Measurement boundaries - } \\
\text { Max/Min emotional shift in } \\
\text { GSR }\end{array}$ & $6.8 / 0.35$ & $4.7 / 0.3$ & $6.6 / 0.49$ & $6.2 / 0.27$ \\
\hline Average value & 3.52 & 2.11 & 3.38 & 3.4 \\
\hline Variance of Time & 5.14 & 0.85 & 3.7 & 146.4 \\
\hline Variance of GSR & 3.01 & 1.64 & 1.84 & 3.15 \\
\hline
\end{tabular}


The results of the conducted experiments indicate a different amount of time that a buyer spends in stores of different types. So, on average, the buyer spends the least amount of time in stores like "Counter store", and the highest at "Market place (Bazar)". It can also be said that the bazaars have the greatest variation in visiting time and, as a consequence, variance on time, and stores like "Counter store" have the least variation. Stores like "supermarket" and "Discounter supermarket" have intermediate variation between the types mentioned above.

As the sampling shows, the difference between the "Counter store" and the "Discounter supermarket" is about $27 \%$ of the increase in the average time spent in the store; between "Discounter supermarket" and "supermarket", there is a $13 \%$ of increase in the average time spent in the store; the increase in the average time spent in shops like "Bazar" is more than 90\% compared to "supermarket".

The shift of level of buyer emotional reaction varies from the store type. According to the GSR data, the buyer will receive the lowest emotional fatigue when visiting "Bazar", and the largest - in the "Discount supermarket". The difference between the shift of the level of buyer emotional reaction between these variants is more than 1.9 times. The shift of the level of buyer emotional reaction between the "Counter store" and "Supermarket" is in average 10\%. Variance of GSR data indicates a wider spread of data comparing with the variance of time.

The shift of level of buyer emotional reaction at the Discounter supermarket described via the time spends inside:

$$
\mathrm{E}_{\mathrm{TS} 1}^{\mathrm{GSR}}=0,165 \mathrm{~T}_{\text {pur }}{ }^{2}
$$

The output shows the model to describe the relationship between $\mathrm{E}_{\mathrm{TS} 2}^{\mathrm{GSR}}$ and of TS $\left(\mathrm{T}_{\text {pur }}\right)$. The equation of the fitted model is:

$$
\mathrm{E}_{\mathrm{TS} 2}^{\mathrm{GSR}}=\left(0,55 \cdot \log \left(\mathrm{T}_{\text {pur }}\right)\right)^{2}
$$

The model to describe the shift of level of buyer emotional reaction at the Supermarket is:

$$
\mathrm{E}_{\mathrm{TS} 3}^{\mathrm{GSR}}=\left(0,098 \cdot \mathrm{T}_{\mathrm{pur}}\right)^{2}
$$

The outcomes shows the results of fitting an reciprocal-Y model to describe the relationship between the shift of level of buyer emotional reaction at market place and time of TS $\left(\mathrm{T}_{\text {pur }}\right)$ :

$$
\mathrm{E}_{\mathrm{TS} 4}^{\mathrm{GSR}}=\left(0,35 \sqrt{\mathrm{T}_{\text {pur }}}\right)^{2}
$$

By the analysis of dependence, the following conclusions can be made.

On the longer routes, the emotional state of the buyer changes less intensively than on short routes. This is due to the mechanisms of human working and adapting. At the same time, the buyer is influenced for a long time by the traffic conditions: road, lighting, weather, traffic and pedestrian flows, and so on. This leads to an increase in the physical and emotional stress of the buyer's body. The reason for choosing a particular store can be fatigue, which, in the buyer's opinion, will arise on the way to the store.

Store parameters determine the change in the state of the buyer when being inside the store. One of the main criteria that affect the emotional state of the buyer is the size (area) and type (format) of the store (8-11). With the improvement of the ergonomic indicators of the store, there is a decrease in the voltage on the body of the driver while driving. The type of the store influences the development of the buyer's actions - the process of purchases, which is expressed in a change in emotional tension and time of shopping (Table 4).

A wide spread of the experimental data under identical conditions, indicates the presence of other factors that also affect the buying process and the emotional reaction of buyers. Among these can be distinguished: the flow of customers, the number of free cash desks, the number of people in the queue, the level of lighting, advertisements, and consumer behavior. All these factors can be taken into consideration and investigated using the systems "Buyer Trade enterprise - Management system - Surrounding” (BTME) (Galkin, et al., 2018).

\subsection{Assessing the shift of level of emotional elastic reaction of buyers}

Calculation results on the shift of level of emotional elastic reaction of buyer factor between the elements of purchase process (5) are presented in Table 4. 
Table 4. Assessing the shift of level of emotional elastic reaction of buyer factor between "the trade service" and "road to store"

(Source: Authors' own research)

\begin{tabular}{|l|c|c|c|c|}
\hline \multicolumn{1}{|c|}{ Type of store } & $\begin{array}{c}\text { Discounter } \\
\text { supermarkets }\end{array}$ & $\begin{array}{c}\text { Counter } \\
\text { stores }\end{array}$ & Supermarkets & $\begin{array}{c}\text { Market } \\
\text { place }\end{array}$ \\
\hline Name of the store & ATB & Grocery & $\begin{array}{c}\text { Silpo, Digma, } \\
\text { Chudo }\end{array}$ & Bazar \\
\hline $\begin{array}{l}\text { The average shift of level of emotional elastic } \\
\text { reaction of buyer factor between TS and road } \\
\text { to store ( } E_{\mathrm{TS} / \mathrm{R}}^{\text {GSR }} \text { ) }\end{array}$ & 1.15 & 1.11 & 0.95 & 0.54 \\
\hline $\begin{array}{l}\text { The average shift of level of emotional elastic } \\
\text { reaction of buyer at TS on time } \\
\left(\mathrm{E}_{\Delta \mathrm{TS} / \mathrm{T}}^{\mathrm{GSR}}\right)\end{array}$ & 1.14 & 0.49 & 0.28 & 0.17 \\
\hline $\begin{array}{l}\text { The average shift of level of emotional elastic } \\
\left.\text { reaction of buyer at road on time ( } \mathrm{E}_{\triangle \mathrm{R} / \mathrm{T}}^{\mathrm{GSR}}\right)\end{array}$ & 0.27 & 0.3 & 0.29 & 0.21 \\
\hline $\begin{array}{l}\text { The average shift of level of emotional elastic } \\
\text { reaction of buyer on time }\end{array}$ & 1.73 & 0.79 & 0.57 & 0.38 \\
\hline
\end{tabular}

The average shift of level of emotional elastic reaction of buyer factor in 2 types of stores is more than $1\left(\mathrm{E}_{\mathrm{TS} / \mathrm{R}}^{\mathrm{GSR}}>1\right)$. It testified that TS had more fatigue than road to store for Discounter supermarkets, Counter stores. Low level of service (according to Table 1) at Market place (Bazar) and Discounter supermarkets caused high shift of level of emotional reaction of buyer. Overall data analysis in supermarkets and bazar showed vice versa reaction of consumers $\left(\mathrm{E}_{\mathrm{TS} / \mathrm{R}}^{\mathrm{GSR}}<1\right)$. Road aroused more emotional fatigue than TS. This explains mostly the surrounding components at the store and on the road to store. The supermarkets are situated at the highway and consumers have to cross the road without any traffic light. It rapidly raised the emotional shift at the end stage of moving to the store (except market A). Road to Bazar took much more time as compared to other stores; therefore, consumers became more relaxed when they walked for a long time.

Experiments showed high level of service, therefore, the average shift of level of emotional elastic reaction of buyer at TS on time at Supermarkets $\left(\mathrm{E}_{\Delta \mathrm{TS} / \mathrm{T}}^{\mathrm{GSR}}\right.$ $=1.14)$. There was dense consumer flow in the store; it remained overcrowded almost all the time, and there were not enough cash desks inside and people were waiting in line for a long time. Bazar had a low level of service, but with a large area. Consumers, when they decided to go to the Bazar, spent more time there, and they were not in a hurry while shopping. So, they were relaxed and stayed in an optimal state at the end of the purchase process. Other stores showed that $\mathrm{E}_{\Delta \mathrm{TS} / \mathrm{T}}^{\mathrm{GSR}}$ level was lower than 1. It shows low level of changing inside of the store during time.

The shift of level of emotional elastic reaction of buyers at TS on time at Counter store has nearly 1 level of $\mathrm{E}_{\mathrm{TS} / \mathrm{R}}^{\mathrm{GSR}}$ because of the buyer being there for a short time period (Fig. 4). Over 20 samples lay under level $\mathrm{E}_{\mathrm{TS} / \mathrm{R}}^{\mathrm{GSR}}<1$, which demonstrates a higher influence of the road to the store than TS on buyers $\left(\mathrm{H}_{1}\right)$.

In all the cases, purchases led to an increase of the emotional fatigue of the consumer. Only when visiting the Bazar and Counter stores, a figure close to 0 was recorded, which indicates that the state of the buyer remains unchanged $\left(\mathrm{H}_{2}\right)$ (Fig. 5). The emotional state of the buyer varies more from the time than from the staying in the store. This fact is related to the environment in which the buyer is located, as well as with the emotional excitement before purchasing (with the thoughts to remember what to buy). 


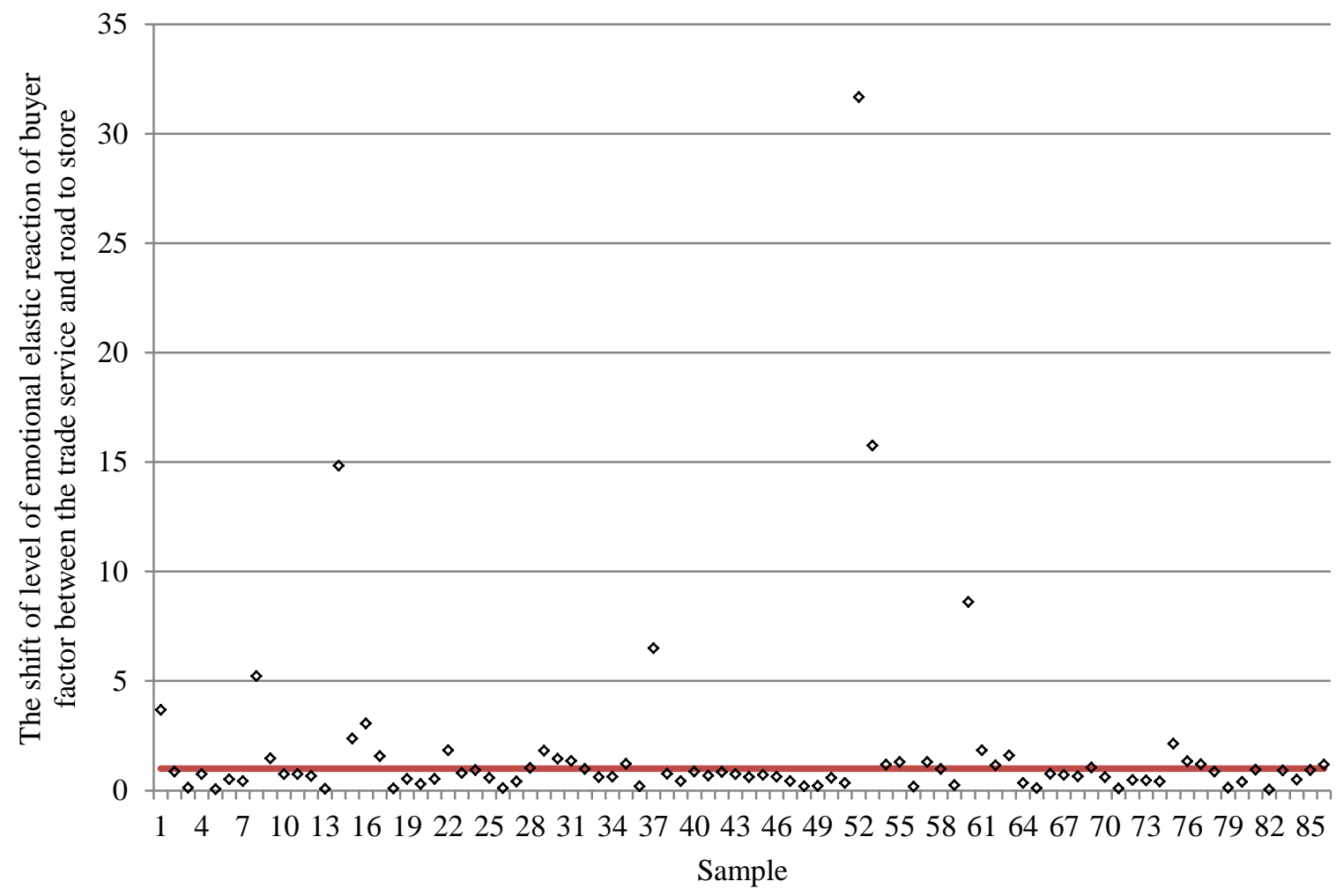

Figure 4. The shift of level of emotional elastic reaction of buyer factor between the trade service and road to store (Source: Authors' own research)

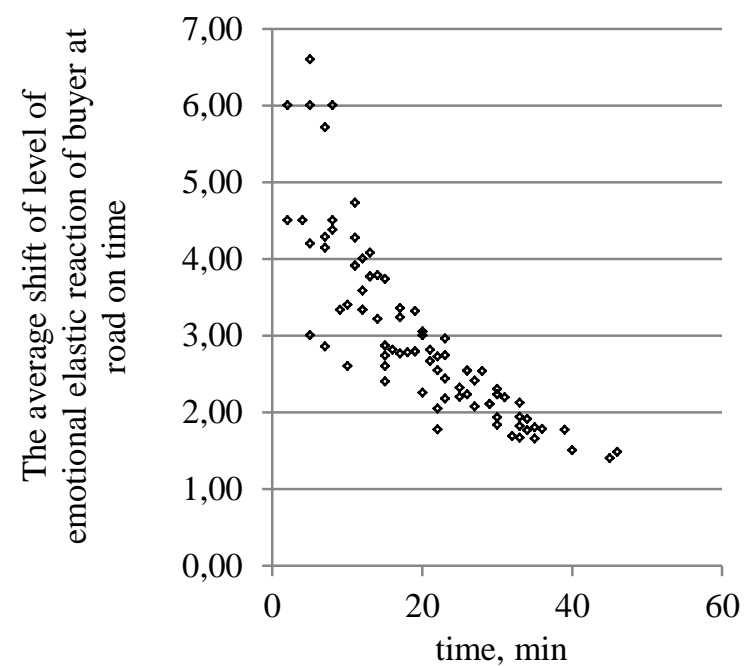

5a) At road on time

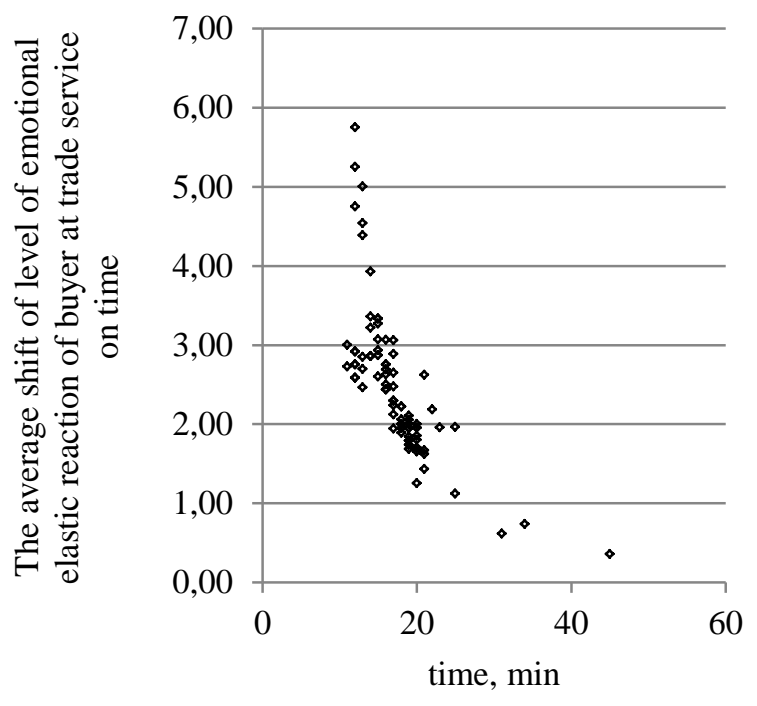

5b) At trade service

Figure 5. The average shift of level of emotional elastic reaction of buyer at elements of purchase process on time (Source: Authors' own research) 
The results of the experiments indicate the influence of the environment (atmosphere) on the state of the buyer, namely:

- a higher level of service in the store causes a lower level of fatigue of the buyer (excluding the bazaar),

- the behavior of the staff (affability, attractive appearance, professional knowledge) provides less fatigue, especially in Counter stores,

- the presence of a large number of buyers in the shopping center increases emotional fatigue, especially in discounter-type stores.

A special influence on this surrounding is provided by the internal components of every person (the visitor of the trading floor), which are not always accessible to the merchandising specialists and the personnel of the trading floor. Unlike many other factors in the atmosphere of the store, mental environment is more subjective, which creates certain difficulties in its operational measurement, control and management. In addition, retailers should understand that a temporary success caused by a mental impact on a visitor can lead to a more sustainable cognitive dissonance of the buyer, which will create problems with the formation of sustainable consumer flows, trust relationships, and so on.

\section{Discussion}

Most of the consumer neuroscience studies are made in laboratory. This is not a realistic environment for end-consumer, so the decision making differs from normal life conditions (Plassmann, et al., 2007). Previously (Halkin, 2016; Halkin, 2018), we described only the method in only a few purchase attempts. This research provides further explanation of emotional fatigue on the type of store. The regression models describing the emotional state of the buyer in stores of different types were obtained. In contrast to the existing approach to planning and evaluating the emotional fatigue of buyers based on polls and the subjective opinion of buyers, our approach is based on the real feelings of the buyer. The presented range of factors covers the traffic conditions in the residential area of Kharkiv, Ukraine. The proposed approach can also be used in any city, provided the range of data variation is extended.
The presented model shows the average value of the indicator of the emotional system of buyers after shopping, which can be used to determine the likelihood of shopping on the basis of emotional fatigue. At the same time, planning a specific trip to the store requires a specific calculation. Presented approach expands the knowledge obtained in solving problems within the framework of the "Buyer - Trade enterprise - Management system - Surrounding" (BTME) approach".

Organoleptic factors in the shopping service of the store's different types are based on several components, which ideally should affect all five sense organs of the buyer (sight, hearing, sense of smell, touch and taste) and cause exceptionally positive emotions. The atmosphere is designed to help the buyer adjust to the retail space and feel comfortable. To do this, the features of visual adaptation - the sensitivity of the eye to various kinds of lighting conditions (darkness, twilight, daylight, artificial lighting); auditory adaptation - the perception of auditory stimuli by a person and his reaction before and after; social adaptation - the process of adaptation of the individual to the external environment; sensory adaptation - reactions to stimuli acting on the sensory organs are taken into account.

Consequently, for discounter-type stores, the number of incentives that act on the buyer should be limited. The appeal to the buyer inside such a store is more effective when it is "restrained" and does not attract much attention. All the sensory components must create a unified image of the store. At Bazar type store, we cannot make this limitation due to the absence of walls. Open space store provide the lowest type of service quality and buyer concentration of attention. For Supermarket type, the departments are used to attract attention of consumers.

The accumulation of people in the store, on the one hand, generates a psychological "crowd effect" (especially at Bazar and Discounter supermarket), and thus, arouses interest among passers-by, but at the same time can lead to a reduction in the visitor's stay in the store or postponement of his non-urgent purchases (Chang, Eckman and Yan, 2011). The absence of buyers in the store's trading floor can sow doubt that the store is popular, or that it has quality goods and adequate price levels. In addition, a rare 
buyer wants to be in the center of attention of unknown people (bored staff) and disrupt the atmosphere of the store by his appearance. Therefore, from a psychological point of view, the Supermarket type, in which people move around the trading floor relatively freely, without hustle and bustle, are most attractive for buyers.

A special influence on this environment is provided by the internal components of every person (the visitor of the trading floor), which are not always accessible for analysis. Unlike many other factors in the atmosphere of the store, mental surrounding is more subjective, which creates certain difficulties in its operational measurement, control, and management. Neuropsychological impact on a visitor can lead to a more sustainable cognitive dissonance of the buyer, which will create problems with the formation of sustainable consumer flows, trust relationships, and so on (Cummings and Venkatesan, 1976; Dennis, et al., 2010).

All the above mentioned circumstances indicate the need for special caution from retailers when exerting psychological influence on the behavior of visitors of the trading floor. The formation of the mental environment of the store has the closest relationship with the moral and ethical standards of doing business. Ideally, the service in the store should not be intrusive, but at the same time, it should not be completely absent. This means that the type of store should always be in the field of view of the buyer, have competent knowledge about all products, but do not flaunt their knowledge - "burdening" the client with a lot of information will only scare him away.

\section{Conclusion and further studies}

Continuous improvement of the management of quality of consumer services can be ensured at the expense of complex and systematic approaches to the development of a system of organizational measures for the formation of standards for trade services in the system of consumer co-operation, which is the prospect of further exploration in this area of research. The high level of shopping service allows retail chains to achieve sustainable competitive advantage and increase quantity of loyal customers (Hamstra, 2012).
The management of the quality of trade services is directed at the formation of rational management decisions on the development of a specific type of store, the coordination of its activities and the high efficiency of its end results at the expense of high dynamism, which takes into consideration changes in the factors of the external environment, resource potential, forms of organization of functioning and management, financial condition and other parameters of the operation of the store's type. In order to optimize management, it is necessary to analyze the data obtained from the results of the diagnostics of the shopping services system within consumer's collaboration; this will provide a variety of approaches for the development of specific management decisions based on the established criteria.

\section{$7 \quad$ References}

[1] Adolphs, R., 2002. Neural Systems for Recognizing Emotion. Current Opinion in Neurobiology, 12(2), pp.169-177.

[2] Afanasieva, I., Galkin, A., 2018. Assessing the Information Flows and Established their Effects on the Results of Driver's Activity. Archives of Transport, 45(1), pp.7-23.

[3] Agarwal, S., Dutta, T., 2015. Neuromarketing and Consumer Neuroscience: Current Understanding and the Way Forward. Decision 42 (4), pp.457-462. DOI:10.1007/s40622-015-0113-1.

[4] Ambler, T., Braeutigam, S., Stins, J., Rose, S., Swithenby, S., 2004. Salience and Choice: Neural Correlates of Shopping Decisions. Psychology \& Marketing, 21(4), p.247-261.

[5] Andreassi, J., 2007. Psychophysiology: Human Behavior And Physiological Response. In Psychophysiology: Human Behaviour \& Physiology Response, Lawrence Erlbaum.

[6] Areni, C. S., Kim, D., 1993. The Influence of Background Music on Shopping Behavior: Classical Versus Top-Forty Music in a Wine Store. ACR North American Advances.

[7] Babin, B. J., Hardesty, D. M., Suter, T.A., 2003. Color and Shopping Intentions: The Intervening Effect of Price Fairness and Perceived Affect. Journal of Business Research, 56(7), pp.541551. 
[8] Baevsky R.M., 1984. Mathematical Analysis of Changes in Heart Rate During Stress. Moscow: Nauka.

[9] Baevsky, R.M., Ivanov, G.G., Chirejkin L.V., etc., 2001. Analysis of Heart Rate Variability with use Various Electrocar Diographical Systems (Methodical Recommendations). The Bulletin of Arrhythmology, 24, pp.65-85.

[10] Bakker, J., Pechenizkiy, M., Sidorova, N., 2011. What's Your Current Stress Level? Detection of Stress Patterns from GSR Sensor Data. In 2011 IEEE 11th International Conference on Data Mining Workshops, pp.573-580, IEEE.

[11] Bellizzi, J. A., Hite, R. E., 1992. Environmental Color, Consumer Feelings, and Purchase Likelihood. Psychology \& Marketing, 9(5), pp.347363.

[12] Bhatt, G., 2017. Effect of Store Atmospherics in Creating Brand Loyalty an Empirical Investigation in Single Brand Retail Context.

[13] Blackwell, R.D., Miniard P.W., Engel, J.F., 2006. Consumer Behavior (10th ed.). Thomson Learning.

[14] Boucsein, Wolfram, 2012. Electrodermal Activity. Springer Science \& Business Media.

[15] Chang, H.J., Eckman, M., Yan, R.N., 2011. Application of the Stimulus-Organism-Response Model to the Retail Environment: the Role of Hedonic Motivation in Impulse Buying Behavior. The International Review of Retail, Distribution and Consumer Research, 21(3), pp.233-249, DOI: $10.1080 / 09593969.2011 .578798$.

[16] Charlton S.G., 2002. Handbook of Human Factors Testing and Evaluation, 2nd. Ed - Mahwah: LEA.

[17] Chebat, J.C., Dube, L., Marquis, M., 1997. Individual Differences in Orcadian Variations of Consumers' Emotional State. Perceptual and Motor Skills, 84(3), pp.1075-1086.

[18] Chebykin, O.Y., Bedny, G., Karwowski, W. (Eds.)., 2008. Ergonomics and Psychology: Developments in Theory and Practice (Vol. 1). CRC Press.

[19] Crosby, L.A., Evans, K.R., Cowles, D., 1990. Relationship Quality in Services Selling: an Interpersonal Influence Perspective. The Journal of Marketing, pp.68-81.

[20] Cummings, W.H., Venkatesan, M., 1976. Cognitive dissonance and consumer behavior: A Re- view of the Evidence. Journal of Marketing Research, pp.303-308.

[21] De Mooij, M., Hofstede, G., 2011. CrossCultural Consumer Behavior: A Review of Research Findings. Journal of International Consumer Marketing, 23(3-4), pp.181-192.

[22] Dennis, C., Newman, A., Michon, R., Brakus, J.J., Wright, L.T., 2010. The Mediating Effects of Perception and Emotion: Digital Signage in Mall Atmospherics. Journal of Retailing and Consumer services, 17(3), pp.205-215.

[23] Etzion, H., Pang, M.S., 2014. Complementary Online Services in Competitive Markets: Maintaining Profitability in the Presence of Network Effects. MIS Quarterly, 38(1), pp. 231-247, DOI: 10.25300/MISQ/2014/38.1.11.

[24] Feuerstein, R., Klein, P.S., Tannenbaum, A.J. (eds.), 1991. Mediated Learning Experience (MLE): Theoretical, Psychosocial and Learning Implications. Freund Publishing House Ltd.

[25] Frenkel, A., 1966. Multivariate Correlation Model of Labor Productivity. Moscow: Economics.

[26] Galkin, A., Prasolenko, O., Obolentseva, L., Atynian, A., Balandina, I., Chebanyuk, K., 2018. The Neuromarketing ICT Technique for Assessing Buyer Emotional Fatigue. CEUR Workshop Proceedings, 2105, pp. 243-253, Access at: http://ceur-ws.org/Vol-2105/10000243.pdf .

[27] Ghobadian, A., Speller, S., Jones, M., 1994. Service Quality: Concepts and Models. International Journal of Quality \& Reliability Management, 11(9), pp.43-66.

[28] Glanert, M., 2012. Behavioral Targeting Pros and Cons - Behavioral Targeting Blog. Behavioral Targeting. Retrieved 31 March 2016, Access at: http://behavioraltargeting.biz/behavioraltargeting-pros-and-cons/.

[29] Grewal, D., Levy, M., Kumar, V., 2009. Customer Experience Management in Retailing: An Organizing Framework. Journal of Retailing, 85(1), pp.1-14.

[30] Halkin, A., 2016. Improving of Quality of Trade Service Through Examination of Consumer's Emotional State. Industrial and Systems Engineering, 1(2), pp.54-60.

[31] Halkin, A., 2018. Emotional State of Consumer in the Urban Purchase: Processing Data. Foundations of Management, 10(1), pp.99-112. 
[32] Hamstra, M., 2012. Study Shows Shopper Behavior. Supermarket News. January 30. Available at: http://supermarketnews.com/consumertrends/study-shows-shopper-behavior [Accessed: 17 Feb 2015].

[33] Jain, R., Bagdare, S., 2011. Music and Consumption Experience: a Review. International Journal of Retail \& Distribution Management, 39(4), pp.289-302.

[34] Jerritta, S., Murugappan, M., Nagarajan, R., Wan, K., 2011, March. Physiological Signals Based Human Emotion Recognition: a Review. In Signal Processing and its Applications (CSPA), 2011 IEEE 7th International Colloquium, pp.410-415. IEEE.

[35] Jun, M., Yang, Z., Kim, D., 2004. Customers' Perceptions of Online Retailing Service Quality and their Satisfaction. International Journal of Quality \& Reliability Management, 21(8), pp.817-840.

[36] Kim, J., Bouchard, C., Bianchi-Berthouze, N., Aoussat, A., 2011. Measuring Semantic and Emotional Responses to Bio-Inspired Design. In Design Creativity 2010, pp.131-138. Springer, London.

[37] Kotler, P., 1973. Atmospherics as a Marketing Tool. Journal of Retailing, 49(4), pp.48-64.

[38] Kotler, P., Armstrong, G., 2010. Principles of Marketing. Pearson Education.

[39] Kotler, Ph., Keller, L.K., 2012. Marketing Management 14th eds, Pearson Education Limited.

[40] Krey, N., Espinosa, J.A., Cao, J.T., 2017, June. A Meta-Analytical Review of PAD Within Retail Environments: An Abstract. In Academy of Marketing Science World Marketing Congress, pp.175-175. Springer, Cham.

[41] Kumar, I., Garg, R., Rahman, Z., 2010. Influence of Retail Atmospherics on Customer Value in an Emerging Market Condition. Great Lakes Herald, 4(1), pp.1-13.

[42] Levy, M., Weitz, B.A., Grewal, D., 2012. Retailing Management (Vol. 6). New York: McGrawHill/Irwin.

[43] Lissovolik, M.B., 2003. Determinants of Inflation in a Transition Economy: The Case of Ukraine (No. 3-126). International Monetary Fund.
[44] Lovelock, C., Patterson, P., 2015. Services Marketing. Pearson Australia.

[45] Lykken, D.T., Venables, P.H., 1971. Direct Measurement of Skin Conductance: A Proposal for Standardization. Psychophysiology, No. 8, pp.656-672.

[46] McGoldrick, P.J., Pieros, C.P., 1998. Atmospherics, Pleasure and Arousal: The Influence of Response Moderators. Journal of Marketing Management, 14(1-3), pp. 173-197.

[47] Minton, E.A, Khale, L.R., 2014. Belief Systems, Religion, and Behavioral Economics. New York: Business Expert Press LLC.

[48] Morrison, M., Gan, S., Dubelaar, C., Oppewal, H., 2011. In-store Music and Aroma Influences on Shopper Behavior and Satisfaction. Journal of Business Research, 64(6), pp.558-564.

[49] Mower, J. M., Kim, M., Childs, M. L., 2012. Exterior Atmospherics and Consumer Behavior: Influence of Landscaping and Window Display. Journal of Fashion Marketing and Management: An International Journal, 16(4), pp.442-453.

[50] Piaget, J., 2017. The child's Conception of Physical Causality. Routledge.

[51] Plassmann, H, Ambler, T, Braeutigam S, Kenning, P., 2007. What can Advertisers Learn from Neuroscience? International Journal of Advertising, 26(2), pp.151-175.

[52] Prasolenko, O., Galkin, A., Burko, D., 2017. Galvanic Skin Response as a Estimation Method of the Driver's Emotional State. American Journal of Science, Engineering and Technology Vol. 2 (1), pp.50-56.

[53] Puccinelli, N. M., Goodstein, R. C., Grewal, D., Price, R., Raghubir, P., Stewart, D., 2009. Customer Experience Management in Retailing: Understanding the Buying Process. Journal of retailing, 85(1), pp.15-30.

[54] Richins, L. M., 1997. Measuring Emotions in the Consumption Experience. Journal of Consumer Research, Vol. 24, No. 2, pp.127-146.

[55] Rigas, G., Katsis C. D., Bougia P., Fotiadis, D. I., 2008. A Reasoning-Based Framework for Car Driver's Stress Prediction, 16th Mediterranean Conference on Control and Automation, pp.627632, 25-27 June 2008.

[56] Woodworth, R.S., Schlosberg, H., 1954. Experimental Psychology. Oxford and IBH Publishing. 